\title{
Atypical Celiac Disease Presenting With Clubbing
}

\section{Çomak Parmak ile Başvuran Atipik Çölyak Hastalığı Olgusu}

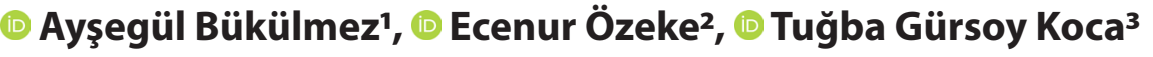 \\ 'Afyonkarahisar Health Sciences University, Faculty of Medicine, Department of Pediatrics, Afyonkarahisar/Turkey \\ 2Iscehisar State Hospital, Afyonkarahisar/Turkey \\ ${ }^{3}$ Isparta City Hospital Isparta/Turkey
}

\begin{abstract}
Celiac disease is an autoimmune disease characterized by inflammation of the small intestinal mucosa due to gluten exposure in individuals with genetic predisposition. Gastrointestinal symptoms such as abdominal pain, diarrhea, loss of appetite and weight loss are seen in majority of the patients. The number of patients presenting with extraintestinal complaints for instance electrolyte disorders, hematologic, muscle, bone, and joint involvement is also considerably high. In this case, we discuss a 12-year-old girl who was recovered from the clinic at 4 months with a gluten-free diagnosis of celiac disease as she presented with complaints of clubbing, developmental delay, and fatigue.
\end{abstract}

Keywords: Clubbing, celiac disease, children

\section{INTRODUCTION}

Celiac disease, also known as gluten-sensitive enteropathy, is an autoimmune, inflammatory multigenetic disease of the small intestine that occurs after dietary gluten exposure in individuals with a genetic predisposition. Clinical findings of celiac disease vary asymptomatic or severely symptomatic depending on the severity of the disease and the degree of mucosal involvement. In addition, the disease may have intestinal and extraintestinal clinical findings. Gastrointestinal symptoms such as abdominal pain, weight loss, weakness, anorexia, diarrhea are common. Less common gastrointestinal symptoms are hypocalcemia, myopathy, osteomalacia, coagulopathy, osteoarthropathy. $[1,2]$

\section{Öz}

Çölyak hastalığı, genetik yatkınlığı olan bireylerde gluten maruziyeti sonucu ince barsak mukozasında inflamasyon ile karakterize otoimmün bir hastalıktır. Hastaların çok büyük bir kısmında karın ağrısı, ishal, iştahsızık, kilo kaybı gibi gastrointestinal sistem yakınmaları görülürken; elektrolit bozuklukları, hematolojik, kas, kemik, eklem tutulumu gibi ekstraintestinal yakınmalarla başvuran hasta sayıs da azımsanmayacak ölçüde çoktur. Burada çomak parmak şikayeti, gelişme geriliği, halsizlik yakınmaları ile başvurarak çölyak tanııı alan glutensiz diyetle 4. ayda kliniği düzelen 12 yaşında bir kız olgu sunuldu. Anahtar Kelimeler: Çomak parmak, çölyak hastalığı, çocuklar

The clubbing (digital clubbing) is an osteoarthropathy of the nail bed, which is characterized by a soft tissue increase, especially in the proximal part of the nail, with anteroposterior and lateral diameter of the nail. It may occur with cystic fibrosis, asthma, bronchiectasis, cyanotic heart disease and various cancers Although it is a rare condition, celiac disease and graves disease are among the treatable causes of clubbing ${ }^{[3-5]}$ In this case, the patient who presented with complaints of fatigue, distortion of the nails, abdominal distension and unresponsive anemia was diagnosed with celiac disease and rapid resolution of her complaints with gluten-free diet treatment was mentioned.

Corresponding (IIletişim): Ayşegül BÜKÜLMEZ - Associate Professor, Afyonkarahisar Health Sciences University, Faculty of Medicine, Department of Pediatrics, Afyonkarahisar / Turkey

E-mail (E-posta): aysegulbukulmez@yahoo.com

Received (Geliş Tarihi): 18.07.2019 Accepted (Kabul Tarihi): 18.12.2019 


\section{CASE REPORT}

A 12-year-old girl admitted to the paediatrics with complaints of deformity in her fingers, loss of appetite and abdominal distention for 2 years. The patient had been diagnosed with anemia several times before and had been given oral iron preparations, but her complaints were not relieved. In physical examination; sluggish appearance, conjunctival pale, clubbing and abdominal distension were present (Figure 1).

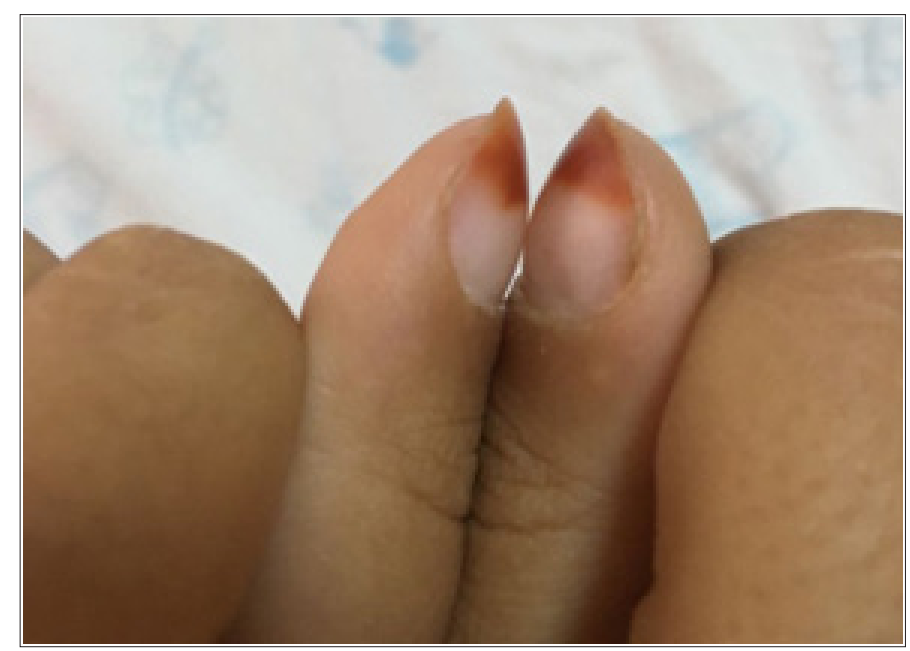

Figure 1. Clubbing

There was no hepatosplenomegaly. In the percussion there was a tympanic sound in the abdomen. Her weight was 30.5 kg (2\% p) Z: -2.08, height: $136 \mathrm{~cm}$ (<3\% p). Z: -2.6 BMI: (21 P)

Z-0.82. In laboratory tests Hgb: 7.4 g/dl Htc: 24\%, 3 MCV: 63, 1 fL MCH: 19.3 pg RDW: 18.8 platelets: 393000 U ferritin: 3, 77 $\mathrm{ng} / \mathrm{ml}$ Folate: $2,29 \mathrm{ng} / \mathrm{ml}$ Vit B12: $154 \mathrm{pg} / \mathrm{ml}$ and 25 OH-D vit: 5 , $4 \mathrm{ng} / \mathrm{ml}$ total protein $4.65 \mathrm{mg} / \mathrm{dL}$ albumin: $2.4 \mathrm{mg} / \mathrm{dl}$, calcium: $7.75 \mathrm{mg} / \mathrm{dl}$ (adjusted calcium $8.6 \mathrm{mg} / \mathrm{dl}$ ), kidney, liver function tests and blood gas was normal. Sedimentation was $19 \mathrm{~mm} / \mathrm{h}$, CRP was $0.19 \mathrm{mg} / \mathrm{dl}$.

Accordingtoage,thepatienthasafairlyregressionofpercentille, tissue transglutaminase $\lg \mathrm{A}: 12.1$, anti-endomysium antibody: positive anti-gliadin Ig A: 7, 54 (negative), Ig A: 73, 3, Recurrent celiac markers from the patient: Transglutaminase Ig A: 22, 5 (positive), Anti-endomysium antibody: weak positive, Anti gliadin Ig A: 6, 39 (negative), Ig A: 143.

Upper gastrointestinal endoscopy was performed. The patient's biopsy was consistent with celiac. A gluten-free diet was started for Celiac. After the treatment, the patient's clubbing was completely recovered and gained weight. VA: 40 $\mathrm{kg}$ (29P) Z: - 0.55 and height was $146 \mathrm{~cm}$ (16 P) BMl: 18.3 (48 P). The patient is still followed up as an outpatient.

\section{DISCUSSION}

Celiac disease is an autoimmune, inflammatory, multigenetic disease in which intestinal mucosa with histologic changes triggered by immunological reactions in individuals with genetic predisposition which develop as a result of exposure of the small intestine mucosa to gluten and various prolamin. Histopathological examination of the small intestine mucosa has increased intraepithelial lymphocytes, villous atrophy in the mucosa, and crypt hyperplasia. Epidemiological studies have shown that the incidence of celiac disease in the world is $0.05-0.1 \%{ }^{[6,7]}$ In a study conducted in our country, the incidence of celiac disease was found to be $0.47 \%$ in 20.190 healthy children in the 6-17 age group. ${ }^{[8]}$

Celiac disease is common with other autoimmune-related diseases (type 1 diabetes mellitus, thyroiditis, sjögren's disease, addison's disease, primary biliary cirrhosis) Antiendomysium antibody against proteins in the intestinal mucosa, serological tests such as tissue Tranglutaminase $\lg \mathrm{A}$ are used in diagnosis of celiac disease. In case that the serological tests are positive; small bowel biopsy and histopathological changes are examined After diagnosis of celiac disease, treatment is a lifelong gluten-free diet. While living in gluten-free diet, patient must avoid wheat, barley, rye-containing products in terms of prognosis of the disease is very important Clinical symptoms are improved within 1-2 weeks with a gluten free diet, whereas mucosal histology returns to normal at 6 months. Serology-specific antibodies become negative within 6 months to 1 year after gluten-free diet. ${ }^{[1,2,6,7]}$

In our case, there were impairment of finger and iron deficiency anemia which did not improve with replacement. After the diagnosis of atypical celiac disease, a gluten-free diet was started and symptoms rapidly regressed. The patient who caught his peers in the development of growth is still followed up by the outpatient clinic.

\section{CONCLUSION}

We emphasized that celiac disease should be kept in mind in the differential diagnosis of patients with clubbing. sağlamları ayırt etme gücü belirlenmiștir. İstatistiksel anlamlııı düzeyi $p<0,05$ olarak alındı.

\section{ETHICAL DECLARATIONS}

Informed Consent: Written informed consent was obtained from all participants who participated in this study.

Status of Peer-review: Externally peer-reviewed.

Conflict of Interest Statement: The authors have no conflicts of interest to declare.

Financial Disclosure: The authors declared that this study has received no financial support.

Author Contributions: All of the authors declare that they have all participated in the design, execution, and analysis of the paper, and that they have approved the final version. 


\section{REFERENCES}

1. Lebwohl B, Sanders,DS Green PHR. Coeliac disease Lancet 2018; 391: 70-81

2. Durham J Heide S. Temples HS.Celiac Disease in the Pediatric Population J Pediatr Health Care. 2018 ;32(6):62731.

3. Hanssen-flaschen J, Nordberg J. Clubbing and hypertrophic osteoarthropathy. Clin Chest Med 1987;8(2): 287-98.

4. Vandemergel $X$, Renneboog B. Prevalence, aetiologies and significance of clubbing in a department of general internal medicine. Eur J Intern Med. 2008;19(5):325-29.

5. Shah K, Rubian Al. Nail Disorders as Signs of Pediatric Systemic Disease Curr Probl Pediatr Adolesc Health Care 2012;42:204-11

6. Hill ID, Dirks MH, Liptak GS, Colletti RB, Fasano A, Guandalini

7. S. et al. Guideline for the diagnosis and treatment of celiac disease in children: Recommendations of the North American Society for Pediatric Gastroenterology, Hepatology and Nutrition. J Pediatr Gastroenterol Nutr. 2005;40(1):1-19.

8. Husby S, Koletzko S, Korponay-Szabó IR, Mearin ML, Phillips A, Shamir $\mathrm{R}$, et al. European society for pediatric gastroenterology, hepatology, and nutrition guidelines for the diagnosis of coeliac disease. J Pediatr Gastroenterol Nutr. 2012;54(1) 136-60.

9. Dalgic B, Sari S, Basturk B, Ensari A, Egritas O, Bukulmez A, Baris Z.;Turkish Celiac Study Group Prevalence of celiac disease in healthy Turkish school children Am J Gastroenterol. 2011 Aug;106(8):1565 Note: Yasar, Aslan. [corrected to Dogan, Yasar]] Am J Gastroenterol. 2011;106(8):1512-17.

10. Moore JK, West SR, Robins G. Advances in celiac disease. Vol. 27, Curr Opin Gastroenterol. 2011; 27(2): 112-18.

11. Kaukinen K, Lindfors K, Collin P, Koskinen O, Maki M. Coeliac disease A diagnostic and therapeutic challenge. Clin Chem Lab Med. 2010;48(9):1205-16. 